\title{
Representations of intergenerational care on BBC children's television
}

Sanna Inthorn

School of Art, Media and American Studies, University of East Anglia, Norwich, UK

School of Art, Media and American Studies, University of East Anglia, Norwich

Research Park, NR4 7TJ, UK; s.inthorn@uea.ac.uk

Sanna Inthorn is Senior Lecturer in Society, Culture and Media at the University of East Anglia. 
Representations of intergenerational care on BBC children's television

This paper contributes to research on media representations of care with a textual analysis of BBC children's television. As a public service broadcaster, the $\mathrm{BBC}$ is tasked with the fostering and sustaining of citizenship. This paper argues that representations of care are an important way by which the BBC can potentially meet its remit and inform children's perceptions of informal care. It takes a focused look at the portrayal of grandparent-grandchild relationships of care in three programmes: 'Mr Alzheimer's and Me', Katie Morag and Topsy and Tim. All three programmes show narrative moments which map onto Tronto's (1998; 2003) concept of good care, including attentiveness, responsibility, competence, responsiveness, solidarity and trust. Grandparents and grandchildren are shown to be caring for each other. However, programmes do not challenge the inequalities which continue to structure the realities of informal care work. Neither the inequalities of power between carers and care receivers, nor the lack of public and government support for carers are addressed, and adult informal care is gendered. This paper argues that while BBC children's programmes provide important opportunities for children to learn the meaning of good care, in order for it to meet its public service remit, it should also provide opportunities to learn about the relationships of power that structure informal care.

Keywords: intergenerational care; representation of care; children's television; BBC; British television

\section{Introduction}

We are basically fighting a losing battle. What keeps us going is that I want to keep my granddad going, so that's basically the main cure. Joshua, 10. ('Mr Alzheimer's and Me'. My Life 2015)

The BBC's 2015 documentary 'Mr Alzheimer's and Me' won much public acclaim for its portrayal of dementia through the eyes of grandchildren. The programme was described as a 'milestone for raising awareness' (Kelly 2015) because it showed 
children's perceptions of dementia, but also because of its positive representation of care. As the Head of Policy and Public Affairs at the Alzheimer's Society commented:

The programme is particularly positive in showing how the grandchildren can provide stimulation to their grandparents who have dementia. ... This emphasises that simply being with the person and showing them love and affection is the most important thing that the child or young person can do. (Alzheimer's Society 2015, para.7)

Intergenerational relationships of care are a recurring theme in BBC children's programmes, including one-off documentaries like 'Mr Alzheimer's and Me', but also fictional programmes such as Topsy and Tim (2014 -) and Katie Morag (2013 - ), two series that tell the stories of children's everyday adventures. In this article I take a focused look at the portrayal of grandparent-grandchild relationships of care in these three programmes. I ask how they represent the role of children as carers, but also whether - from the perspective of Joan Tronto's conceptualisation of care ethics (1998; 2013), these representations constitute examples of good care.

The programmes analysed here are broadcast on BBC's children's channels Cbeebies and CBBC. The former is aimed at children aged 2-6, the latter at children aged 6-12. For research on media representations of care, BBC children's programmes are of particular interest: Children are at the forefront of care. Not only will they be expected to meet the rising demand for informal care in the future, as carers and citizens (UK Parliament 2013), but many already act as carers or auxiliary carers for a family member (The Children's Society 2012; Orel et al. 2004). Children's television offers an important resource for children to explore their role in relationships of care, but also the meaning of good care. Children and teenagers use media, including pre-school television, to find out 'what is going on in the world' (Carter et al. 2009), to explore their social values, their relationship with other social groups (co-author's name et al. 2013; Buckingham 2000), as well as their concept of what family means (Callister et al. 2007, 142). As a public service broadcaster, the BBC has a particular responsibility to help children develop a sense of responsibility to care and to explore the meaning of good care. It is tasked with contributing to citizenship and civil society (Northam 2005, 249), a public purpose which the BBC Trust reaffirmed in its 2013 review of children's programming (BBC Trust 2013). Historically, representations of the family have played an important role in the articulation of this public purpose (Godfrey and Holmes 2016). Representations of the family 
stress the importance of social ties and rehearse social values such as the importance of sharing and tolerance, relationships and values commonly associated with democratic citizens (Buckingham 1995; Godfrey and Holmes 2016). Caring is a civic activity and attitude. Not only do carers make a valuable contribution to society but caring itself is motivated by 'civic virtues', such as altruism (Herd and Harrington Meyer 2002). Therefore, a key way by which the BBC's commitment to citizenship can be explored is by asking what resources it provides to help children develop a sense of responsibility to care.

In the UK, children as young as five care for their siblings, parents, grandparents, other relatives or non-relatives (The Children's Society 2013, 6-9). In this paper I focus on representations of children as carers in grandparent-grandchildren relationships. For many children a grandparent's care needs is the first experience of care in the family. They notice the emotional and physical strain felt by their parents who provide care, but they also act as auxiliary caregivers. Grandchildren report that they are responsible for a variety of tasks such as feeding, monitoring, or providing emotional support (Orel et al. 2004; Pakeham and Cox 2012). Moreover, in their relationship with their grandparents, children are confronted with the complex relationships of power that characterise informal care (Tronto 1998, para. 15). Grandchildren are care providers but they are also dependant on their grandparents. Often referred to as a 'hidden army of carers' grandparents make 'significant time and financial contributions towards their grandchildren's upbringing' (Save the Children 2014). Opportunities to explore the meaning of intergenerational care through children's television therefore are an important way of preparing children for their future as adult carers, but for many, they are also a way of making sense of their current relationships of care.

Research in health communication and media studies has started to analyse representations of care. This paper contributes to this still small field. In doing so, it makes an empirical and a conceptual contribution. Firstly, it explores the role of children's television with a public service remit. Existing empirical work from media studies and health communication has analysed representations of care across a range of media forms and genres, including medical drama, cinema, newspapers and magazines (Van Gorp and Vercruysse 2012; McHugh 2012; author's name and co-author's name 2015). While there are studies which ask how BBC children's television constructs concepts of citizenship (Northam 2005) and demonstrates its commitment to diversity 
and citizenship through a caring mode of address towards its audience (Holdsworth 2016), there is currently no study which asks how BBC children's television represents intergenerational relationships of care.

The conceptual contribution of this study to existing research is its application of care ethics and specifically the work of Joan Tronto $(1998 ; 2013)$ to media analysis. One of the most influential works in ethics of care (Olthuis 2014), Tronto's model is particularly useful for an analysis of media representations of care. It is an inclusive model which captures the wide range of activities, knowledges and predispositions that characterise the realities of everyday informal care. It allows me to pay attention to the many different ways in which an audio-visual text, such as a children's television programme, might represent everyday moments of care. Moreover, it is a model that speaks to media studies' interest in the ideological work of media representations, as it highlights the relationships of power that characterise the experience of care for both recipients and providers of care.

Tronto (1998) identifies four phases in the process of caring: (1) caring about, which involves becoming aware of and paying attention to the need for caring, including unspoken needs. It requires the care giver to decide which needs to care about; (2) taking care of, which involves assuming responsibility for the identified care needs, organising personnel and resources to make care happen; (3) care giving, which involves the delivery of care and meeting the identified care needs; and (4) care receiving, which involves the care recipient responding to the care they receive. Each of these phases requires certain virtues and knowledge by which good care can be judged: attentiveness, responsibility, competence, solidarity and trust, and responsiveness. Tronto stresses the relational nature of care. Relationships of care should be built on solidarity and trust (Tronto 2013, 161), virtues evidenced by carers and care recipients alike. For good care to happen, care recipients need to be open to care and signal to the carer whether care needs have been met. Good care involves dialogue between carers and care recipients.

Tronto's care ethics describes the activities and attributes that encompass good care giving and receiving, but it is also concerned with the social and political structures that enable or hinder good care. The phases and virtues of caring she describes are an ideal and as Tronto herself argues in reality, the process of care is 'fraud with conflict' (1998, para. 15). It is only by addressing and challenging the imbalances of power that 
structure the experience of care that a change in the overall public value associated with care becomes possible. For informal carers conflicts may arise at the personal level because they need to balance their own needs and those of others. There are often imbalances of power between carers and care receivers. Carers may have abilities, knowledge or resources that care receivers do not have and can take advantage, but at the same time care receivers might be in a financially, politically and culturally privileged position which is out of reach for the carers (Tronto 1998). This is perhaps most apparent in formal care work (cp. Leutz 2012), but it also applies to familial care where inclusion about decision-making is shaped by social location such as age, gender, and class (St-Amant et al. 2012, 430). At the social and political level, carers may experience a struggle to gain public recognition and government support for their work (Singleton and Fry 2015). In my empirical analysis I therefore not only ask whether and how children's television shows examples of Tronto's phases and virtues of caring, but also if children's television addresses the conflicts that characterise the realities of care.

\section{Method}

For my analysis I selected three case studies: Topsy and Tim (CBeebies 2014 - ); Katie Morag (CBeebies 2013 - ); and 'Mr Alzheimer's And Me' (My Life, 2015. Series 6, Episode 3). Of the two series, I included in the sample all episodes broadcast in 2015, which for Topsy and Tim were episodes from series one, two and three and for Katie Morag episodes from series one and two. Based on the children's books by Jean and Gareth Adamson, Topsy and Tim follows the everyday adventures of twins Topsy and Tim. Two frequently appearing older characters are their grandmother Jean and $\mathrm{Mr}$ Rosen, a neighbour who visits the twins and uses their father's community bus for older people. Another fictional series and based on the popular children's books by Mairi Hedderwick, Katie Morag tells the adventures of Katie Morag on the fictional Scottish island of Struay. Her grandmothers, Grannie Island and Grannie Mainland are frequently appearing characters. 'Mr Alzheimer's And Me' is an episode of the Bafta award winning documentary series My Life. It tells the story of three children, Ellie, Hope and Joshua who all have a grandparent living with dementia.

The unit of analysis for this study are representations of care involving children and their grandparents, or people who perform the role of a grandparent within their 
kinship network, both hereafter referred to as 'grandparents'. In order to collate my sample, I worked with an inclusive concept of care as a meeting of needs. Tronto suggest that caring, on the most general level, can be viewed as an activity that includes

everything we do to maintain, continue and repair our "world" so that we can live in it as well as possible. That world includes our bodies, ourselves and our environment, all of which we seek to interweave in a complex, lifesustaining web. (Fisher and Tronto 1990, cited in Tronto 1998, para.5)

This definition is much looser than the often precisely defined lists of care activities which can be found in some empirical studies of care. Relevant work in psychology and health (Pakenham and Cox 2012) but also in intergenerational research (Orel et al. 2004) for example identifies a range of care-giving activities undertaken by youth carers. These include instrumental support (e.g. filling out forms), personal intimate support (e.g. dressing), socio-emotional support (e.g. keeping company) and domestic household chores (e.g. shopping). However, in this study I do not approach the meaning of care as fixed, but as culturally negotiated (cp. Foss 2013, 331). A television programme is one of many public sites where the meaning of care is constructed and where socially dominant ideologies may be sustained or challenged. Several perspectives might be offered within the same or across different programmes. When determining which perspectives a television programme offers it is important to pay attention to the conventions of the media form. Theoretical and often abstract models from care ethics do not always neatly map onto articulations of care in the media (author's name and co-author's name 2015). Children's television is not made for an adult audience, let alone an audience of care ethicists. Therefore, rather than trying to 'spot' examples of caring activities identified by existing empirical studies, I included in my sample moments that correspond closely to traditional and perhaps more narrow concept of care, such as grandchildren responding to a grandparent's health need (e.g. reminding to take medication), but also moments where grandparents and grandchildren share an activity without there being a significant need of assistance (e.g. grandchildren helping to wash a dog). In the second step of my analysis, guided by Tronto's model of care, I then conducted an in-depth qualitative analysis of my sample. Central here were the following guiding questions, which allowed me to ask whether, from the perspective of care ethics, BBC children's television provides opportunities for children to learn the 
meaning of good care, including the need to address the relationships of power that structure the experience of care.

(1) Are children shown to be attentive to grandparents' care needs?

(2) Are children shown to be taking responsibility to address these needs?

(3) Are children shown to be delivering care competently?

(4) Are children and grandparents shown to be in dialogue about care needs and the effectiveness of care?

(5) Are relationships of care between children and grandparents represented as underpinned by solidarity and trust?

(6) Are relationships of power that structure the care relationship acknowledged?

Following the approach adopted by other qualitative textual analyses of television texts (Foss 2013; Wilson 2012), I focused on the verbal and visual depictions of characters and narrative structure (Iedama 2001).

\section{Findings}

All three programmes I analysed depict grandparents and grandchildren in reciprocal relationships of care. Grandparents feature as main and as auxiliary carers. In ' $\mathrm{Mr}$ Alzheimer's and Me' Hope lives with her grandparents rather than her father and entire episodes of both Topsy and Tim and Katie Morag are constructed around grandparents' babysitting their grandchildren (Katie Morag, 2015; Series 1, Episode 14; Topsy and Tim, 2015. Series 2, Episode 18. Series 2). Grandparents are depicted as family members who teach grandchildren values and skills for life. For example, when a new baby sister in the family takes everyone's attention away from Katie Morag, Granny Island helps her rediscover the importance of sharing (Katie Morag 2015, Series 1, Episode 10). Grandchildren in turn are shown to be supporting their grandparents who need help with chores, or struggle with health problems such as restricted mobility and memory loss. For example, Topsy and Tim make an 'exercise bucket' for Mr Rosen who is wheelchair bound after an operation (Topsy and Tim, 2015. Series 2, Episode 22) and Hope helps her grandmother with the laundry, cleaning and finding things in the house: 
Hope: Me and nanny do the washing and cleaning together and I make sure she doesn't forget anything.

Mary: Hope, do you want to help Nana look for these biscuits? Erm, erm, ... the toothbrush? I've checked everywhere.

Hope: So you've checked in the fridge?

(My Life, 2015. Series 6, Episode 3)

Tronto suggests that it is only by 'embracing care as a part of human life' and by 'recognizing its role in creating interconnections and relationships of receiving and giving over a lifetime' that it become possible to 'rethink some of the ways in which we now seem unable to cope with human vulnerability' (1998, para. 8). The programmes in my sample make a positive contribution to this public re-evaluation of care. They represent care as something everyone experiences, irrespective of their health status or age. Moreover, they suggest that children and grandparents are connected through a lifelong relationship of care where the roles of care recipient and care giver are not fixed.

\section{Noticing and responding to care needs}

Narratives of entire episodes are driven by children's attentiveness to care needs and taking responsibility to meet them. The moment when a child notices a grandparent's needs functions as an enigma or 'problem' and the narrative follows the child on their quest to find a solution. For example, at the start of 'Katie Morag and the Grumpy Grannie' Katie suspects that something is wrong when Grannie Island, who has indeed hurt her back, misses their ritual of saying good-night by flashing torches through the window (Katie Morag 2015. Series 1, Episode 16). She alerts her parents and enlists the help of Grannie Mainland to make sure Grannie Island is being looked after. Similarly, 'Mr Alzheimer's and Me' introduces three grandchildren who want to help their grandparents. For example, at the start of the programme, the audience is introduced to Ella, who talks to camera about her relationship with her grandad: 'It is hard sometimes. I worry about what he's thinking. If he's happy or if he's upset because he is in his own world'. In the next scene she tells the audience that she has 'decided to do a sponsored walk' to raise money to put 'towards medicines and the care homes' for people with dementia. The audience then gets to follow how Ella puts her plan into action (My Life, 2015. Series 6, Episode 3). 
Without exception, narratives across the sample suggest that children's attempts to provide care are successful and appreciated. Through dialogue and body language, including laughing and smiling, grandparents signal their appreciation for the help they received. Even Granny Island, who initially is reluctant to accept help, in the end communicates here appreciation. Grannie Mainland helps her with hands-on spinal adjustment and the episode concludes with the two grannies and Katie laughing together. At the finishing line of Ella's sponsored walk, her grandfather, with the help of other family members, tells everyone how happy he is that the whole family came together. He kisses Ella and sings a song about her being beautiful. Ella's story concludes with her sitting next to her grandad and speaking to camera, affirming the success of her care initiative:

Before it was quite hard for me to communicate with him and I did not really know how to. When he laughs and sings it makes me happy because I know then that he is happy. (My Life, 2015. Series 6, Episode 3)

Dialogue, but also body language signals that care is an emotionally rewarding experience. In 'Mr Alzheimer's and Me', Joshua, reflects on the success of a memory box he has made for his grandad. The experience he says helped him feel ready for secondary school. 'Helping grandad' he tells the audience, 'has made me feel a bit grown up' (ibid.). In Topsy and Tim camera work signals the twins' happiness at being able to help Mr Rosen feel less lonely. They promise to wave at him on their way to school and embrace him in a big group hug. At the end of this scene, a close-up of the children's smiles signals the happiness they derive from having provided care:

Mr Rosen: But I want to be out of this wheelchair by the time you two start school Topsy and Tim. And do you know why?

Topsy and Tim: No.

Mr Rosen: Well, I can stand at my window and see the children walk over the footbridge and then I'll be able to watch and wave at you both from my window. Every day. When my legs are better.

Tim : And we'll wave to you everyday from the footbridge on the way to school.

Topsy and Tim: We promise.

Topsy: We really, really promise.

Mr Rosen: And I promise too [laughs].

They hug [camera medium close-up on Topsy and Tim smiling]. 
(Topsy and Tim, 2015. Series 2, Episode 22)

\section{Competence}

When determining whether children are shown to be providing care 'competently' (Tronto 1998), it is important to keep in mind that children's television is not the same as an ethical guide to professional nursing practice (e.g. Lachman 2012) for example. The children that feature across my sample are not shown to possess detailed medical knowledge. In 'Mr Alzheimer's and Me', children do explain symptoms of dementia and with the help of Ella's voiceover and a graphic illustration, the documentary does show how the condition affects certain parts of the brain. However, none of the programmes in my sample suggest that medical knowledge is necessary in order to be caring.

Grandchildren are depicted using their knowledge of their knowledge of their grandparent's bodies and habits, but also dialogue to identify whether and what kind of help is needed. For example, Katie Morag notices that Grannie Island is 'the only person who did not seem excited' about the upcoming wedding of Grannie Mainland and through dialogue she identifies her grandmother's sadness about her relationship with her husband (Katie Morag 2015. Series 1, Episode 26). Similarly, by talking to her grandmother and her friends at a day care centre, Hope learns about the importance of social contact and emotional support:

Hope: How do you feel when Mr Alzheimer's comes out?

Friend 1: It's hard to describe. We get through it because we are strong. Because we are all together.

Friend 2: Yes.

Mary: Now you understand why I come home here and come home happy?

Because I'm with nice people and I have fun here don't I?

(My Life, 2015. Series 6, Episode 3)

When they provide care, children are shown to be taking on activities that are appropriate to their developmental stage and experience of the world as children. Caring appears as something that is achievable for children, something that they can do. In Topsy and Tim, the twins decide to decorate a bucket for Mr Rosen so that he can use it for his strength exercises. They use the tools that are available to them - their sandpit bucket, pens and paper. In 'Mr Alzheimer's and Me', Ella says 
Even though the pills won't make Mr Alzheimer's go away forever I still hope Nanny feels better. I make her happy by doing silly things and I tell her how much I love her. And we forget about Mr Alzheimer's.

(My Life, 2015. Series 6, Episode 3)

All programmes emphasize that caring can be learnt and that trying is better than doing nothing, even if one is not sure exactly whether or how one's attempts to care are effective. On a mission to raise awareness for her sponsored walk, Ella visits a radio studio. She tells the radio host:

The people who would say what is the point in going to see him if he can't understand anything. It's better to try than not to try. It makes a difference. (ibid.)

Some of the care activities in which children are shown to be engaging, seem simple. Tronto's work allows us to recognise the importance of such seemingly simple actions for an ethical approach to care. She emphasises that care work requires a certain 'knowhow' and judgement but she also suggests that judgements should be made 'as well as possible' (Tronto 1998: para18). The programmes I analysed here all show children making judgements and taking actions that are appropriate to their world and competencies as children, at a particular developmental stage. The children on CBeebies are of pre-school age and the care they provide includes, for example, Topsy and Tim decorating a bucket which they hope will help Mr Rosen do his exercises. The children on CBBC's 'Mr Alzheimer's and Me' are of school-age and carry out more complex care tasks, such as a sponsored walk. Children are depicted as coming up with their own solutions, or as Katie Morag says 'little plans' (Katie Morag 2015. Series 1, Episode 26) to help. When help is needed for which they are too young, such as a hands-on spinal adjustment, they enlist the support of an adult. Thus children of all ages are shown as willing but also able to provide competent and successful care.

\section{Politics of care}

The examples I have discussed so far neatly map onto Tronto's phases and values of care. Children and grandparents are depicted in relationships characterised by high degrees of solidarity and a reciprocal exchange of care. Children are attentive to 
grandparents' needs and take responsibility for care. Their care is competent and successful. BBC children' television therefore provides an important resource children may use to explore the meaning of 'good care'. However, as I suggested in the introduction, Tronto's model is an ideal concept and if we want to understand the wider social significance of media representations of care, we also need to ask whether they address the politics that structure the experience of care.

The programmes I analysed here do not refer to conflicts between carers and care recipients. Grandparents feature as carers of children and as adults with the knowledge to teach children how to care. They therefore appear in roles of power. However, the narratives ascribe children a considerable degree of agency as well. Their care efforts are shown to be appreciated and they come up with 'special plans' which in the end surprise and help their grandparents.

The programmes I analysed all depict informal intergenerational care as something that is valued. This depiction does not match the experiences of informal carers in the UK who feel that neither the government nor the wider public adequately value their contribution to society (Fry et al. 2011; Singleton and Fry 2015). Claimants of the UK's Carer's Allowance for example report feeling ashamed or embarrassed for claiming benefits. Against the context of increasing welfare cuts, there is a public perception of a 'benefits problem' and benefit claimants feel they are perceived as 'work shy' and 'benefit scroungers (Briant et al. 2012; Singleton and Fry 2015). The programmes analysed here can be criticised for failing to openly acknowledge the difficulties informal carers experience. Some of these difficulties are the result of complex welfare policies, which perhaps are not suitable for children's programmes, especially those aimed at pre-school children. However, the societal context of informal care could be acknowledged, for example by storylines about stigma experienced by carers.

Similarly, programmes could but fail to address the gendering of care work. Examples of intergenerational care work undertaken by children in my sample are not gendered. Boys and girls are shown to be attentive to care needs and taking responsibility to meet them. However, in Topsy and Tim there are examples of gendered representations of care performed by (parent) adults. Indeed, the programme has received considerable public criticism for its traditional representation of gender. Angry parents took to social media describing the programme as 'flabbergastingly sexist' 
(Dixon 2013) in terms of its prescriptive roles for both parents and children. The following comment on social media summarises well the programme's recurring tropes: 'Mummy and Topsy do the washing while Tim helps daddy with the man's work' (ibid.). This gendering of familial roles is also evident in the representation of parents' care roles. The twins' mother is a stay-at-home mum whose role is focused on child care, household chores and looking after her mother when she is ill. In contrast, their father runs a company called 'Helpful Drivers' which provides transports for people with mobility issues, such as Mr Rosen. He relies on his mother to put the twins to bed when his wife is away and he wants to go and play football:

Topsy: Mummy's away this week.

Tim: And dad is going to play football.

Topsy: So grandma is doing our bedtime (Topsy and Tim, 2015. Series 2, Episode 18)

Representations like this are not a step towards the radical rethinking of interdependency and human vulnerability envisioned by Tronto (1998). They are, however, representative of a long tradition of gendered narrative roles in children's television. Current programmes show a diverse range of family types, including the nuclear family, but also single-parent families and kinship groups. However, family roles such as motherhood and fatherhood, remain gendered (Godfrey and Holmes 2016)

\section{Conclusion}

Across my sample, I found narrative moments that mapped onto Tronto's concept of good care. Overall, I therefore argue that BBC children's television provides the resources which are essential for an understanding of what it means to care well for an older family member. BBC children's television portrays intergenerational care as a relationship built on solidarity and trust. It highlights the importance of being attentive to grandparents' needs and trying to find out their wishes, even if communication is difficult. It shows that caring means taking responsibility to meet those needs and trying one's best to do so well. It shows how care involves checking if needs have been met, but also being thanked for one's efforts. 
Importantly, grandchildren and grandparents are shown to be in need of care and to be caring for each other. In this regard, intergenerational care is shown as an exchange over a lifetime. By recognising that care is not a problem that concerns only the elderly, but one that affects everyone, a change in the overall public value associated with care becomes possible. The programmes I have analysed here represent care in this way and my findings suggests that BBC children's television is an important resource children can use to explore the meaning of good care.

However, the programmes I have analysed here do not address or challenge the inequalities that structure the realities of informal care. Caring is represented as conflict free. The question that remains then is whether children's programming should address these conflicts. CBBC and CBeebies address young children and it might seem misguided to expect programmes which are likely to be watched by children, including children who are still at nursery, to explore in depth what ultimately is a complex web of interrelated factors, including government policy, social attitudes, demographic change, and familial contexts. However, as citizens, children have the right to learn about the politics that inform public and private life. In his analysis of production processes behind Newsround, the CBBC's news programme, Matthews (2009) suggests that competition over the child audience, but also a perception of children as unable to understand detailed background information, has led to a formula of producing 'palatable', lively and upbeat programmes that foreground the drama of events rather than the politics that underpin them (Matthews 2009, 553). Like Matthews, I recognise that children's programming is made with children's perspectives and interests in mind. However, assumptions about what children want or can understand has implications for their cultural rights. The BBC is not tasked with shielding children from complex issues. It has a remit to educate and to help children understand the world around them. This world is complex but children value opportunities to learn. Moreover, they want the BBC to represent them (Carter et al. 2009). Young carers who look after an adult and perform similar or much more complex care activities than those shown in the programmes analysed here, they also have a right to be represented. Based on the sample analysed here I therefore argue that BBC children's programming is only partially fulfilling its commitment to citizenship. By providing opportunities to learn the meaning of good care and to understand care as something that everyone needs at some point in their life, BBC children's programmes make an important contribution to a 
change in public perceptions of informal care which should enable the carers of the future. However, by not addressing and discussing the politics that structure care, children's programming does not provide its audiences with the resources they need to also address the social inequalities that structure the realities of care work. To what extent children would use those resources can of course only be established through reception studies. However, what textual analysis as I have presented it here can already show, is that BBC children's programming could do more to meet its remit to foster a caring society.

\section{References}

Alzheimer's Society, 2015. Children open up about dementia in CBBC documentary. Accessed 20 April 2016. https://www.alzheimers.org.uk/site/scripts/news_article.php?newsID=2301

Author's name, initial and co-author's name, initial. 2015. Full reference removed for the purpose of blind peer review.

BBC Trust. 2013. Review of the BBC's children's services. Summary Report. BBC. Accessed 13 April 2016.

http://downloads.bbc.co.uk/bbctrust/assets/files/pdf/our_work/childrens_services/summ ary_report.pdf

Briant, E., Watson, N., and Philo, G. 2013. "Reporting disability in the age of austerity: the changing face of media representation of disability and disabled people in the United Kingdom and the creation of new 'folk devils"'. Disability \& Society 28(6): 874-889.

Buckingham, D., 1995. "Child-centered television? Teletubbies and the Educational Imperative." In Small Screens: Television for Children, edited by D. Buckingham, 38-60. Leicester: Leicester University Press.

Buckingham, D. 2000. The making of citizens: Young people, news, and politics. London: Routledge.

Callister, M., Robinson, T., and Clark, BR. 2007. "Media portrayals of the family in children's television programming during the 2005-2006 season in the US." Journal of Television and Media 1(2): 142-161. 
Carter, C., Messenger Davies, M., Allan, S. and Mendes, K., Milani, R. and Wass, L., 2009. What do children want from the BBC?: Children's content and participatory environments in an age of citizen media. Cardiff: Cardiff University. Accessed 20 April 2016. http://www.bbc.co.uk/blogs/knowledgeexchange/cardi...

Co-author's name, initial., author's name, initial., co-author's name, initial. 2013. Full reference removed for the purpose of blind peer review.

Dixon, H. 2013. "BBC accused of sexism over new children's show Topsy and Tim." The Telegraph.co.uk. Accessed 13 April 2016. ://www.telegraph.co.uk/culture/tvandradio/bbc/10464918/BBC-accused-ofsexism-over-new-childrens-show-Topsy-and-Tim.html

Foss, K.A. 2013. “'That's Not a Beer Bong, It's a Breast Pump!' Representations of Breastfeeding in Prime-Time Fictional Television." Health Communication 28: $329-340$.

Fry, G., Singleton, B., Yeandle, S., and Buckner, L. 2011. Developing a clearer understanding of the Carer's Allowance claimant group. Department for Work and Pensions, Research Report No 739. Accessed 13 April 2016. http://www.sociology.leeds.ac.uk/assets/files/Circle/developing-a-clearerunderstanding.pdf

Godfrey, S. and Holmes, S. 2016. "'Surely the most natural scenario in the world': Representations of 'family' in BBC preschool television." Critical Studies in Television 11(1): 59-77.

Herd, P. and Harrington Meyer, M. 2002. "Care Work: Invisible Civic Engagement." Gender and Society 16(5): 665-688.

Hodgetts, D. and Chamberlain, K. 2003. "Television documentary in New Zealand and the construction of doctors by lower socio-economic groups." Social Science \& Medicine 57(1)" 113-124.

Holdsworth, A. 2015. "Something special: Care, pre-school television and the dis/abled child." Journal of Popular Television 3(2): 163-178.

Holmes, S. 2016. Revisiting Play School: A historical case study of the BBC's address to the pre-school audience. The Journal of Popular Television 4(1): 29-47. 
Iedema R. 2001. “Analysing Film and Television: A Social Semiotic Account of Hospital: An unhealthy business." In Handbook of visual analysis, edited by T. Van Leeuwen and C. Jewitt, 183-204. London: Sage.

Katie Morag, 2015. Series 1, Episode 10. Katie Morag and the Tiresome Ted. TV, CBeebies. Jul 26.

Katie Morag, 2015. Series 1, Episode 16. Katie Morag and the Grumpy Granny. TV, CBeebies. Aug 30.

Katie Morag, 2015. Series 1, Episode 26. Katie Morag and the Wedding - Part 2. TV, CBeebies. Jan 25.

Katie Morag, 2015. Series 2, Episode 4. Katie Morag and the Sick Sheep. TV, CBeebies. Dec 24.

Kelly, P. 2015. "Children talking about dementia on TY is a milestone in awareness raising." The Guardian. Accessed 20 April 2016. http://www.theguardian.com/society/2015/feb/03/children-dementia-cbbcgrandparents-mr-alzheimers-and-me

Lachman, V.D. 2012. "Applying the Ethics of Care to Your Nursing Practice." Ethics, Law and Policy 21(2): 112-115.

Leutz, W. 2011. "The Changing Face of Long-Term Care and How a New Immigrant Workforce Will Shape Its Future.” GENERATIONS - Journal of the American Society on Aging 34(4): 89-96.

Lupton, D., and McLean, J. 1998. "Representing Doctors: Discourses and Images in the Australian Press." Social Science \& Medicine 46(8): 947-958.

Matthews, J. 2009. “'Making It Our Own': BBC Newsround Professionals and Their Efforts to Build a News Agenda for the Young." Television \& New Media 10(6): 546-563.

McHugh, K. 2012. "Nurse Jackie and the politics of care." Nursing Outlook 60: 12-18.

Milne, A. 2010. “The 'D' word: Reflections on the relationship between stigma, discrimination and dementia." Journal of Mental Health 19(3): 227-233.

My Life, 2015. Series 6, Episode 3. Mr Alzheimer's and Me. TV, CBBC. Feb 4.

Northam, J.A. 2005. "Rehearsals in Citizenship: BBC Stop-Motion Animation Programmes For Young Children.” Journal for Cultural Research 9(3): 245263. 
Olthuis, G., Kohlen, H. and Heier, J. 2014. Moral Boundaries Redrawn. The Significance of Joan Tronto's Argument for Political Theory, Professional Ethics and Care as Practice. Leuven: Peeters Publishers.

Orel, N.A., Dupuy, P. and Wright, J. 2004. "Auxiliary Caregivers: The Perceptions of Grandchildren Within Multigenerational Caregiving Environments." Journal of Intergenerational Relationships 2(2): 67-92.

Pakenham, K.I. and Cox, S. 2012. "The nature of caregiving in children of a parent with multiple sclerosis from multiple sources and the associations between caregiving activities and youth adjustment overtime." Psychology and Health 27(3): 324-346.

Save the Children. 2014. "1.9 Million cut working hours to look after grandchildren". Save the Children. Accessed 31 August 2016. http://www.savethechildren.org.uk/2014-07/19-million-cut-working-hours-lookafter-grandchildren

Singleton B.E. and Fry, G. 2015. “Citizen Carer: Carer's Allowance and Conceptualisations of UK Citizenship.” Journal of Social Policy 44(3): 549566.

Stables, J. and Smith, F. 1999. “'Caught in the cinderella trap': narratives of disabled parents and young carers." In Mind and Body Spaces: Geographies of Illness, Impairment and Disability, edited by R. Butler and H. Parr, 256-268. London: Routledge.

St-Amant , O., Ward-Griffin, C., DeForge, R.T., Oudshoorn, A., McWilliam , C., Forbes, D. , Kloseck, M., Hall, J. 2012. "Making Care Decisions in Home-Based Dementia Care: Why Context Matters." Canadian Journal on Aging 31(4): 423434.

The Children's Society. 2013. "Hidden from view: the experiences of young carers in England". The Children's Society. Accessed 31 August 2016. http://www.childrenssociety.org.uk/sites/default/files/tcs/report_hidden-fromview_young-carers_final.pdf

Tronto, J.C. 2013. Caring Democracy: Markets, Equality and Justice. New York: New York University Press. 
Tronto, J.C. 1998. An ethic of care. Generations 22(3), 3. Available from Academic Search Complete. EBSCOhost. Accessed 13 April 2016.

UK Government. 2016. Carer's Allowance. Accessed 10 April 2016. https://www.gov.uk/carers-allowance/overview

UK Parliament. 2013. Ready for Ageing? Select Committee on Public Service and Demographic: First Report. Accessed 13 April 2016.

http://www.publications.parliament.uk/pa/ld201213/ldselect/ldpublic/140/14003 $\underline{. h t m \# a 8}$

Van Gorpa, B., and Vercuyssea, T. 2012. "Frames and counter-frames giving meaning to dementia: A framing analysis of media content." Social Science and Medicine 74 (8): 274-1281.

Wilson, S. 2013. "Dramatising Health Care in the Age of Thatcher." Critical Studies in Television 7(1): 13-28. 